\title{
PENGETAHUAN TENTANG HAZARD DALAM PEMBERIAN ASUHAN KEPERAWATAN UNTUK KESELAMATAN DAN KESEHATAN KERJA
}

(K3)

\author{
Fransiska Finishia Putri Zalukhu \\ vinisiazal12@gmail.com
}

\section{LATAR BELAKANG}

Menurut International Labour Organization (ILO) (1998) Keselamatan dan Kesehatan Kerja (K3) adalah suatu promosi, perlindungan dan peningkatan derajat kesehatan yang setinggi tingginya mencakup aspek fisik, mental, dan social untuk kesejahteraan seluruh pekerja di semua tempat kerja. Pelaksanaan K3 merupakan bentuk penciptaan tempat kerja yang aman, bebas dari pencemaran lingkungan sehingga mampu mengurangi kecelakaan kerja dan penyakit akibat kerja. salah satu bentuk upaya untuk menciptakan tempat kerja yang aman, sehat, bebas dari pencemaran lingkungan, sehingga dapat mengurangi dan atau bebas dari kecelakaan kerja dan penyakit akibat kerja yang pada akhirnya dapat meningkatkan efisiensi dan produktivitas kerja

Bahaya adalah sumber, situasi atau tindakan yang berpotensi mencederai manusia atau sakit penyakit atau kombinasi dari semuanya (Puspitasari,2010). Kurniawan (2008) mengatakan bahwa Hazard adalah faktor faktor intrinsik yang melekat pada sesuatu berupa barang atau kondisi dan mempunyai potensi menimbulkan efek kesehatan maupun keselamatan pekerja serta lingkungan yang memberikan dampak buruk. Pengertian atau definisi Hazard ialah segala sumber, situasi ataupun aktivitas yang berpotensi menimbulkan cedera atau kecelakaan kerja dan atau penyakit akibat kerja - defenisi OHSAS 18001:2007. Secara umum terdapat 5 (lima) faktor bahaya K3 di tempat kerja, antara lain: faktor Bahaya Biologi (Seperti : Jamur, Virus, Bakteri, dll.), Faktor Bahaya Kimia (Seperti: Gas, Debu, Bahan Beracun, dll.). Faktor Bahaya Fisik/Mekanik (Seperti : Mesin, Tekanan, dll.), Faktor Bahaya Biomekanik (Seperti : Posisi Kerja, Gerakan, dll.), Faktor Bahaya Sosial Psikologis (Seperti : Stress, Kekerasan, dll). Potensi bahaya atau dapat disebut juga dengan hazard terdapat hampir disetiap tempat dimana dilakukan suatu aktivitas, baik di rumah, di jalan, maupun di tempat kerja. Apabila hazard tersebut tidak dikendalikan dengan tepat akan dapat menyebabkan kelelahan, sakit, cedera, dan bahkan kecelakaan yang serius. Oleh karena itu, harus dilakukan pengendalian bahaya dengan menemukan sumber-sumber bahaya di tempat kerja, kemudian diadakan identifikasi bahaya. Bahaya yang telah teridentifikasi perlu dievaluasi tingkat risikonya terhadap tenaga kerja. Dari kegiatan tersebut dapat diupayakan suatu usaha pengendalian sampai pada tingkat yang aman bagi tenaga kerja, aset perusahaan, dan lingkungan. 
Menurut ILO, Keselamatan dan Kesehatan Kerja (K3) adalah menjaga dan meningkatkan kesejahteraan fisik, mental dan sosial seluruh para pekerja dan pada semua sektor pekerjaan, mencegah pekerja terjangkit penyakit yang disebabkan oleh kondisi pekerjaan, melindungi pekerja dari risiko yang berdampak buruk pada kesehatan, menempatkan dan menjaga pekerja dalam lingkungan yang sesuai dengan kondisi fisiologi dan psikologi, menyesuaikan pekerjaan dengan pekerja serta pekerja dengan pekerjaannya (Markkanen, PK, 2004).

\section{METODE}

Penelurusan literatur berupa Buku, majalah, Koran, Jurnal print maupun jurnal online, Thesis, disertasi tentang bagaimana pemahaman tentang hazard baik dalam lingkungan kerja terutama dalam memberikan asuhan keperawatan. Setiap lingkungan kerja harus membuat perencanaanyang efektif agar tercapai keberhasilan dalam penerapan sistemn manajemen K3 dengan sasaran yang jelas untuk mencegah resiko dan hazard dalam lingkungan kerja terutama dalam memberikan asuhan keperawatan. Perencanaan yang meliputi: mengidentifikasi sumber bahaya, membuat peraturan, menetapkan tujuan dan sasaran, melaksanakan program kerja serta melakukan pengorganisasian.

\section{HASIL}

Melalui pengkajian literatur ditemukan bahwa, dalam lingkungan kerja kecelakaan kerja adalah sesuatu yang tidak terencana, tidak terkontrol, dan sesuatu hal yang tidak diperkirakan sebelumnya sehingga mengganggu efektivitas kerja seseorang. Penyebab kecelakaan kerja dibagi menjadi lima, yaitu faktor man, tool / machine, material, method, environment, bahan baku, dan faktor lingkungan. (Wijaya, Panjaitan, Palit, 2015). Dalam kegiatan sehari-hari diketemukan potensi sumber bahaya mudah dijumpai dalam berbagai situasi lingkungan, terlebih di rumah sakit saat melakukan asuhan keperawatan. Menurut ILO (2003) setiap hari rata-rata 6000 orang meninggal akibat sakit dan kecelakaan kerja atau 2,2 juta orang per tahun. Sebanyak 350.000 orang per tahun di antaranya meninggal akibat kecelakaan kerja. Kecelakaan kerja juga berakibat pada biaya 1000 miliar USD atau 20 kali dana bantuan yang diberikan ke negara berkembang.

Perawat merupakan petugas kesehatan dengan presentasi terbesar dan memegang peranan penting dalam pemberian pelayanan kesehatan. Dalam menjalankan tugasnya perawat berisiko mengalami gangguan kesehatan dan keselamatan kerja (K3). Dengan adanya pengetahuan tentang pengendalian atau upaya pencegahan hazard maka dapat meminimalisir kecelakaan kerja di lingkungan rumah sakit. Adapun kasus yan pernah terjadi pada tanggal 27 maret 2016 di rumah sakit singapura terjadi kasus nyata kekerasan fisik dan verbal pada saat perawat sedang melakukan 
pengkajian perawat tersebut pada saat melakukan pengkajian kepada pasien mendapatkan kekerasan fisik sekaligus verbal dari pasien yang ia kaji seperti yang dikutip dalam suatu artikel di media online. Pelaksanaan K3 akan mewujudkan perlindungan terhadap tenaga kerja dari risiko kecelakaan kerja dan penyakit akibat kerja yang dapat terjadi pada waktu melakukan pekerjaan di tempat kerja. Dengan dilaksanakannya perlindungan K3, diharapkan akan tercipta tempat kerja yang aman, nyaman, sehat dan tenaga kerja yang produktif, sehingga akan meningkatkan produktivitas kerja dan produktivitas perusahaan. Dengan demikian K3 sangat besar peranannya dalam upaya meningkatkan produktivitas perusahaan, terutama dapat mencegah korban manusia. Dengan demikian untuk mewujudkan K3 perlu dilaksanakan dengan perencanaan dan pertimbangan yang tepat, dan salah satu kunci keberhasilannya terletak pada peran serta pekerja sendiri baik sebagai subyek maupun obyek perlindungan dimaksud dengan memperhatikan banyaknya risiko yang diperoleh.

Hasil penelitian di beberapa negara membuktikan bahwa rumah sakit adalah salah satu tempat kerja yang berbahaya dan perawat adalah salah satu petugas kesehatan yang berisiko untuk mengalami gangguan kesehatan dan keselamatan kerja akibat dari pekerjaannya. Sebagai gambaran, biro statistik ketenagakerjaan dan Konsil Nasional Asuransi Amerika (2013) menyimpulkan pada rumah sakit di Amerika setiap 100 jam kerja terjadi 6,8 kejadian kecelakaan kerja dan penyakit akibat kerja (PAK). Angka ini menempatkan kecelakaan kerja dan PAK di rumah sakit sedikit lebih tinggi dibanding dengan kecelakaan kerja dan PAK di sektor lainnya seperti sektorkonstruksi manufaktur dan pelayanan profesional dan bisnis lainnya. Sebanyak $48 \%$ kecelakaan kerja disebabkan karena penggunaan tenaga otot yang berlebihan oleh perawat ketika menangani pasien, seperti mengangkat, memindahkan atau menjangkau pasien, dan peralatan medis lainnya. Selain itu, $549 \%$ jenis kecelakaan yang dialami berhubungan dengan gangguan musculoskeletal seperti sprain dan sirala otot, dan hal ini menempatkan gangguan muskuloskeletal sebagai penerima klaim kompensasi terbesar dari biaya rumah sakit. Kerugian material yang harus dikeluarkan dari kecelakaan kerja dan PAK setiap tahunnya sekitar 2 Milyar USS.

Setiap tindakan yang dilakukan oleh perawat mempunyai potensi bahaya berupa bahaya fisik, biologi, dan ergonomi. Bahaya fisik didapatkan pada pekerjaan yang menggunakan alat yang tajam, seperti memasang infus dan menjahit luka. Bahaya biologi terdapat pada tindakan invasif merawat luka, memasang infuse, dan memberikan obat melalui rektal. Sedangkan postur janggal ketika membungkuk merupakan bahaya pekerjaan karena faktor ergonomi. 


\section{PEMBAHASAN}

Perawat merupakan salah satu tenaga medis yang memberikan pelayanan kesehatan. Kesehatan dan keselamatan perawat perlu mendapatkan perhatian lebih dibandingkan komponen pelayanan kesehatan lainnya karena tiup harinya mereka bertemu langsung dengan pasien dan bahaya-bahaya yang ada di rumah sakit. Untuk mengetahui bahaya yang mengancam kesehatan dan keselamatan perawat dilakukan suatu identifikasi. Identifikasi bahaya yang didapatkan dari hasil studi literatur dan studi lapangan dengan wawancara, dikelompokkan menjadi lima kategori yaitu biological hazard. chemical hazard physical hazard, pshvchological hazard dan environmental and mechanical biomechanical hazard. Istilah "hazard" atau potensi bahaya menunjukkan adanya sesuatu potensial untuk mengakibatkan cidera atau penyakit, kerusakan atau kerugian yang dapat dialami oleh tenaga kerja atau perusahaan. Sedang kemungkinan potensi bahaya yang manifest, sering disebut resiko. Baik "hazard" atau "resiko" tidak selamanya menjadi bahaya, asalkan pengendaliannya dilaksanakan dengan baik. Di tempat kerja, kesehatan dan kinerja seorang pekerja sangat dipengaruhi oleh:

1. Beban kerja berupa beban fisik, mental dan sosial, sehingga upaya penempatan kerja yang sesuai dengan kemampuannya perlu diperhatikan.

2. Kapasitas kerja yang banyak tergantung pada pendidikan, ketrampilan, kesegaran jasmani, ukuran tubuh, keadaan gizi dan sebagainya.

3. Lingkungan kerja sebagai bahan tambahan, baik berupa faktor fisik, kimia, biologi, ergonomi maupun aspek psikososial.

Berbagai potensi bahaya kesehatan dan kemungkinan dampaknya, antara lain:

1. Faktor mesin/peralatan cidera, kecelakaan kerja.

2. Fisiologik atau beban kerja : gangguammuskolusketal. low back pain, kelelahan. 3 Faktor fisik : noise induced hearing loss, gangguan neura vaskuler, efek radiasi

4. Faktor kimia intoksikasi, alergi, kanker.

5. Faktor biologik: infeksi, alergi 6. Faktor psikologik : Stress psikis, depresi, ketidakpuasan.

7. Faktor psikososial : Konflik, monotoni, kualitas kerja

Penerapan kesehatan kerja membutuhkan kerjasama berbagai keahlian/profesi berbagai disiplin, seperti kedokteran. keperawatan. higiene kerja/industri, toksikologi, epidemiologi, ergonomic keselamatan kerja. hukum, lingkungan, psikologi. Termasuk juga partisipasi pihak pekerja dan komitmen pengusaha/perusahaan. Hazard atau bahaya dapat dihindari ataupun dampak dari hazard tersebut dapat diminimalkan. Menurut PERMENAKER No. 05/MEN/1996, pengendalian risiko kecelakaan dan penyakit akibat kerja dilakukan dengan berbagai macam metode, yaitu : 
1. Pengendalian teknis atau rekayasa yang meliputi eliminasi, subtitusi, isolasi, ventilasi, higiene, dan sanitasi (engineering control).

2. Pendidikan dan pelatihan.

3. Pembangunan kesadaran dan motivasi yang meliputi sistem bonus, insentif, penghargaan, dan motivasi diri.

4. Evaluasi melalui internal audit, penyelidikan dan etiologi.

5. Penegakan hukum.

6. Pemberian alat pelindung diri/ APD

Alat Pelindung Diri (APD) adalah pilihan terakhir yang dapat dilakukan untuk mencegah paparan bahaya pada pekerja. Penggunaan APD ini disarankan hanya digunakan bersamaan dengan penggunaan alat pengendali lainnya. Dengan demikian perlindungan keamanan dan kesehatan personel akan lebih efektif.

Secara umum, tujuan keperawatan kesehatan kerja adalah menciptakan tenaga kerja yang sehat dan produktif. Tujuan hyperkes dapat diperinci sebagai berikut (Rachman. 1990):

1. Agar tenaga kerja dan setiap orang yang berada di tempat kerja selalu dalam keadaan sehat dan selamat

2. Agar sumber-sumber produksi dapat berjalan secara lancar tanpa adanya hambatan.

Dalam melakukan proses pengkajian dan perencanaan pada pasien, perawat harus memperhatikan hazard dan resiko yang kemungkinan terjadi, seperti :

1. Pelecehan verbal saat berkomunikasi dengan pasien dan keluarga.

2. Kekerasan fisik pada perawat ketika melakukan pengkajian.

3. Pasien dan keluarga acuh tak acuh dengan pertanyaan yang diajukan perawat.

4. Resiko tertular penyakit dengan kontak fisik maupun udara saat pemeriksaan fisik.

5. Perawat menjadi terlalu empati dengan keadaan pasien dan keluarganya.

Dalam mengkaji pasien, perawat pun harus menyadari akan adanya hazard dan resiko yang mungkin mereka dapatkan. Berikut beberapa upaya yang perlu dilakukan untuk mecegah terjadinya kekerasan fisik dan verbal pada perawat saat melakukan pengkajian:

1. Perawat harus melaporkan setiap adanya tindakan kekerasan dalam bentuk apapun kepada pihak rumah sakit.

2. Memberikan pengertian kepada pasien agar memperlakukan sesama manusia dengan dasar martabat dan rasa hormat. 
3. Dalam melakukan kontak kepada pasien, perawat seharusnya menjadi pendengar yang baik. Salah satu teknik pengumpulan data pada pengkajian adalah wawancara. Saat melakukan wawancara, perawat harus mampu menempatkan diri sebagai tempat curhat pasien sebaik mungkin.

4. Memberikan pelatihan dan pendidikan kepada perawat tentang cara menghindari tindakan kekerasan verbal dan fisik.

5. Ketika pasien terlihat sedang dalam keadaan tidak terkontrol dan susah untuk didekati, perawat dapat melakukan pengkajian kepada keluarga pasien terlebih dahulu.

6. Saat mengkaji, perawat tidak boleh menyampaikan kata-kata yang menyinggung pasien dan keluarganya.

7. Saat melakukan tindakan pemeriksaan fisik, perawat harus meminta persetujuan dari pasien terlebih dahulu.

8. Manajemen rumah sakit perlu memfasilitasi perawat mempersiapkan diri untuk menghadapi hazard dan resiko.

9. Manajemen harus terbuka serta tidak berusaha menutupi terhadap laporan-laporan kekerasan fisik maupun verbal terhadap perawat.

10. Memodifikasi lingkungan yang nyaman di rumah sakit mulai dari poli, ruangan rawat inap, sampai ke unit gawat darurat dan ruang intensif untuk menentramkan suasana hati pasien dan keluarga.

Upaya pencegahan resiko tertular penyakit dari pasien ke perawat maupun dari perawat ke pasien:

1. RS menyediakan APD yang lengkap seperti masker, handscoon, scout dll untuk meminimalisir terjadinya atau tertularnya penyakit/ infeksi yang dapat terjadi terutama saat bekerja, APD harus selalu di gunakan sebagai pelindung diri.

2. Menyediakan sarana untuk mencuci tangan atau alkohol gliserin untuk perawat. Cuci tangan merupakan cara penanganan awal jika kita sudah terlanjur terpapar cairan pasien baik pasien beresiko menularkan atau tidak menularkan.

3. RS menyediakan pemilahan tempat sampah medis dan non medis. Bila sampah medis dan non medis tercampur dan tidak dikelola dengan baik akan menimbulkan penyebaran penyakit.

4. RS menyediakan SOP untuk tindakan keperawatan. SOP merupakan salah satu cara atau parameter dalam meningkatkan mutu pelayanan.

Upaya Mencegah dan Meminimalkan Resiko dan Hazard pada Perawat dalam Tahap Pengkajian Bedasarkan Kasus Penyakit Akibat Kerja: 
1. Batasi akses ke tempat isolasi

2. Menggunakan APD dengan benar

3. SOP memasang APD, jangan ada sedikitpun bagian tubuh yang tidak tertutup APD

4. Petugas tidak boleh menyentuh wajahnya sendiri

5. Membatasi sentuhan langsung ke pasien

6. Cuci tangan dengan air dan sabun

7. Bersihkan kaki dengan di semprot, ketika meninggalkan ruangan tempat melepas APD

8. Lakukan pemeriksaan berkala pada pekerja

9. Hindari memegang benda yang mungkin terkontaminasi.

\section{PENUTUP}

Perawat merupakan petugas kesehatan dengan presentasi terbesar dan memegang peranan penting dalam pemberian pelayanan kesehatan. Dalam menjalankan tugasnya perawat berisiko mengalami gangguan kesehatan dan keselamatan kerja (K3). Dengan adanya pengetahuan tentang pengendalian atau upaya pencegahan hazard maka dapat meminimalisir kecelakaan kerja di lingkungan rumah sakit. Untuk mengetahui bahaya yang mengancam kesehatan dan keselamatan perawat dilakukan suatu identifikasi. Identifikasi bahaya yang didapatkan dari hasil studi literatur dan studi lapangan dengan wawancara, dikelompokkan menjadi lima kategori yaitu biological hazard. chemical hazard physical hazard, pshvchological hazard dan environmental and mechanical biomechanical hazard. Istilah "hazard" atau potensi bahaya menunjukkan adanya sesuatu potensial untuk mengakibatkan cidera atau penyakit, kerusakan atau kerugian yang dapat dialami oleh tenaga kerja atau perusahaan. Sedang kemungkinan potensi bahaya yang manifest, sering disebut resiko. Baik "hazard" atau "resiko" tidak selamanya menjadi bahaya, asalkan pengendaliannya dilaksanakan dengan baik. 


\section{DAFTAR PUSTAKA}

Elbilgahy, A. A., Elwasefy, S. A., and El Aziz, M. A.(2019). Occupational Hazards and Safety Nursing Guideness for Pediatric Nursing In The Health Care Setting. Journal of Health, Medicine, and Nursing. 59. 73-82

Farihah, T.(2016). MANAJEMEN RESIKO DAN ANALISIS HAZARD SEBAGAI DASAR MANAJEMEN KESELAMATAN DAN KESEHATAN KERJA DI UKM LOGAM (STUDI KASUS: WL ALUMUNIUM). Integrated Lab Journal 4(1), 77-86

Hidayah, W. F.(2019)."Analisis Faktor Risiko dan Hazard dalam Implementasi Keperawatan". Skripsi Fakultas Ilmi Kesehatan.Keperawatan S1. UMP.

Joshua, R., \& Karkada, S.(2017). A Riview an Occupational Health Hazards and its Consequences among Nurses. International of Nursing Reaserch and Practice. 4 (2)

Mandal, J. (2013) NSI: A major occupational hazards among the health care workers in Nepal. International Journal of Occupational Safety and Health, 3(1), 22 - 25.5

Ramdan, I. M.,dkk.2017. Analisi Risiko Kesehatan Dan Keselamatan Kerja (K3) Pada Perawat.Jurnal Kesehatan. 5 (3)

Ramadhan, F.(2017). Analisis Kesehatan dan Keselamatan Kerja (K3) Menggunakan Metode. Seminar Nasional Riset Terapan. ISSN: 978-602-73672-1-0

Simamora, R. H. (2011). ROLE CONFLICT OF NURSE RELATIONSHIP WITH PERFORMANCE IN THE EMERGENCY UNIT OF HOSPITALS RSD DR. SOEBANDI JEMBER. The Malaysian Journal of Nursing, 3(2), 23-32.

The Sentinel Watch. (2020). Nurse Face Workplace Hazards. Nursing \& Healthcare Management. (Article)

Wallis \& Laura.(2015). OSHA Gets Serious About Workplace Safety for Nurses. AJN The American Journal of Nursing. 15(9), 13

Wijaya, A., Panjaitan, W.S. \& Palit, H.C. 2015. Evaluasi Kesehatan dan Keselamatan Kerja dengan Metode HIRARC pada PT. Charoen Pokphand Indonesia. Jurnal Tirta. 3. (1). 29-34. 